Sáfrán József ${ }^{1}$

\title{
Az információszerzés fontossága Szun-ce, Taj Kung, Machiavelli, Zrínyi, Jeney, Clausewitz és Jomini hadelméleti müveiben
}

\author{
The Importance of Information Acquisition \\ in the Theoretical Works of Sun-Ce, Taj Kung, \\ Machiavelli, Zrínyi, Jeney, Clausewitz and Jomini
}

\begin{abstract}
Absztrakt
A hatalom birtokosainak erejét az mutatja meg, hogy mennyi információt sikerül eltitkolniuk. Azt, hogy hogyan védik meg saját titkaikat, és szerzik meg az ellenfélét, évezredek óta foglalkoztatja a gondolkodókat. A tanulmány célja feltárni Szun-ce, Taj Kung, Machiavelli, Zrínyi, Jeney, Clausewitz és Jomini müveiben a hírszerzés fontosságát. Ehhez célszerü áttekinteni mit gondolnak a kémek helyzetéröl, a hírszerzés infrastruktúrájáról, a bizalmi pozíciókról, a felderítés fontosságáról. Olyan tanulságokat vonunk le, amelyek koronként azonosak és a mai modern gondolkodásunkba is beépithetök.
\end{abstract}

Kulcsszavak: hírszerzés, felderités, hadelmélet, hadtörténet

\section{Abstract}

The power of the holders of power is shown by how much information they manage to conceal. How they protect their own secrets and acquire their opponent's secrets is a huge question for war theorists. The aim of the study is to explore the importance 
of intelligence in the works of Sun-Ce, Taj Kung, Machiavelli, Zrínyi, Jeney, Clausewitz and Jomini. To achieve this, it is advisable to review what they think about spies, intelligence infrastructure, positions of trust, and the importance of reconnaissance. We will draw lessons that are the same for all ages and can be incorporated into our modern thinking.

Keywords: intelligence, reconnaissance, military theory, military history

\section{Bevezetés}

A hadtudományi gondolkodók évezredek óta foglalkoznak a háború milyenségének vizsgálatával. Már az első leírt művekben is találkozhatunk a titok fontosságával, és hogy mennyire fontos az, hogy az ellenség titkait megszerezzük, amíg a sajátjainkat a lehető legnagyobb titokban kell tartsuk. A tanulmány célja nem más, mint a klasszikus hadtudományi szerzők - Szun ce, Taj Kung, Machiavelli, Zrínyi, Jeney, Clausewitz és Jomini - szerzeményeit elemezve bemutassa, hogy miként vélekedtek a kémekröl, a hírszerzési metódusokról és rendszerekről, a bizalomról vagy magáról a felderítés lényegéről. Bemutatunk olyan gondolatokat, amelyek még a mai hadi vagy biztonsági környezetünkben is megállják a helyüket.

A hadtudomány jeles képviselőit a Nemzeti Közszolgálati Egyetem Hadtudományi Doktori Iskolájának $A$ hadtudomány klasszikusai I-II. címü előadásán ismertetett szerző́k közül választottam ki. Fontos szempont volt, hogy az illetőt lehessen a gondolkodó jelzővel illetni, és ne csupán gyakorlati tapasztalatait leíró hadvezérként vagy katonai szakemberként tartsák számon tudományos körökben. A témával foglalkozók elméleteivel könyvtárakat lehetne megtölteni, így azok a tudósokat emeltem ki, akik valamilyen szempontrendszerük szerint kiemelten foglalkoztak a felderítéssel és hírszerzéssel.

\section{Szun-ce ${ }^{2}$ és Taj Kung ${ }^{3}$}

A hadtudomány egyik első és legfontosabb alapmüve Szun-cétől $A$ háború müvészete. Az alkotás az időszámításunk előtt 5. században íródott a híres kínai hadvezér tollából. A háború müvészetének 13. fejezete teljes egészében a kémek alkalmazásával foglalkozik, bár már az előző cikkelyekben is óriási figyelmet szentel a felderítés fontosságának. Szun-ce szerint a háborúban az ellenség feltérképezése a legfontosabb, mindent meg kell előznie: ismerni szükségeltetik az ellenség gondolkodását, hadműveleteit, taktikáját, felszerelését lehetőségeit. Aki e tudás birtokában van, az sohasem veszíthet: „A győzelem legfőbb feltétele az előzetes tudás, amely érdekében titkos ügynököket kell alkalmazni."4

Szun-ce (kb. i. e. 544 -i. e. 496) ókori kínai író, hadvezér, hadtudós és filozófus. A hadtudomány egyik első képviselője, máig nagy hatású gondolkodója. A hadművészeti kánon hét könyve egyikének szerzője.

3 Taj Kung (i. e. 11. század körül) kínai író, országának egyik legkorábbi hadvezére. A hadmüvészeti kánon hét könyve egyikének szerzője.

4 Szun-ce: A háború müvészete. Budapest, Helikon, 2015. 58-60. 
A hadvezérnek szükséges gyakorlatiasan gondolkodni. A siker érdekében kizár mindenféle szellemekből és spirituális dolgokból levont következtetéseket, elveti a különböző számítgatásokat, spekulációt. Bölcs fejedelem és kiváló hadvezér csakis úgy indít háborút, hogy már a lehető legtöbb információt előre megszerezte, kiemelkedő tudásának révén mindent tud előre, és az előzetes tudás birtokában pragmatikus döntéseket hoz.

A jó hadvezér mindeközben természetesen figyel az elhárításra is, hiszen az ellenség ugyanúgy alkalmazhat kémeket, ahogy ő teszi: „Az országunkba küldött ellenséges személyeket meg kell találnunk." 5

A hadvezér ötféle kém együttes alkalmazását javasolja, és ha mind az ötfajta kémet egyszerre használjuk, az egy olyan hálót eredményez, ahol senki nem ismeri fel a célunkhoz vezető utat, és kézben tudjuk tartani a legváratlanabb helyzeteket is. Az ötféle kémtípus közül első a megtelepedett kém, akit a védekező ellenség lakosságából választunk ki és fogadunk szolgálatunkba: de facto egy terület fejedelmének állampolgára fogja belsős információkkal segíteni munkánkat. Belső kém az, akit az ellenség hivatalnokai közül választunk ki és ismereteivel hozzájárulhat különböző területek infrastruktúrájának és lakosságának megismeréséhez. A visszatérő kém nem más, mint mai terminológiával jellemezve egy megfordított hírszerző, akit az ellenség kémei közül szervezünk be. Ez legfőképpen arra biztosít lehetőséget számunkra, hogy az ellenség felderítő tevékenységét hatékonyabban tudjuk feltérképezni, valamint hamis információkkal lássuk el, amivel megtéveszthetjük a fogadó felet. A halál kéme az, aki soha semmilyen körülmények között nem fedi fel kilétét, megtévesztő tevékenységet folytat az ellenség sorai között, és a saját kémeinknek is hamis híreket ad tovább, ezáltal saját embereink lojalitását, híreik megbízhatóságát is tudjuk ellenőrizni. Végül az élet kéme, aki nem más, mint aki az ellenségtől hírrel tér vissza. ${ }^{6}$ Szun-ce úgy véli, hogy az elhúzódó háborút mindenképpen kerülni kell, hiszen rendkívüli módon megviseli a fejedelem gazdasági és katonai tartalékait. Ha konfliktusra kerül sor, azt minél előbb le kell zárni, ennek minél gyorsabb megtételéhez pedig óriási szükség van kémekre, ezért a kémeknél busásabb jutalmat soha ne kapjon senki. ${ }^{7}$ Szun-ce szerint a vitás kérdések megoldása első körben a diplomácia, ám ha nem érünk el vele sikereket, akkor nyúlhatunk a kémeink szolgáltatásaihoz, amelyek akár aljas módszerek is lehetnek, kezdve az ellenséges parancsnok meggyilkolásától az ivóvíz megmérgezéséig. Ez akár felesleges hadmüveletektől is megvédheti az országot. A kémeket bárhol és bármikor alkalmazni lehet és kell is. ${ }^{8}$

Érdemes még a kínai hadművészeti kánon hét könyve közül megemlíteni Taj Kung $A$ háború törvényei című művét. A Párduc tanítása című fejezetnél csatlakozik Szun-céhez: az ellenséget folyamatosan, megállás nélkül figyelni kell, mindig körültekintően kell a helyzetét felderíteni, a terepviszonyokat megismerni, városok és erődítmények elhelyezkedését ismerni, utánpótlásmagukat felderíteni. A tevékenységekhez minél erősebb felderítőhálózatot kell kiépíteni és alkalmazni, amihez fontos a folyamatosság. A szerző indoklása szerint a lehetőségek nem végtelenek:

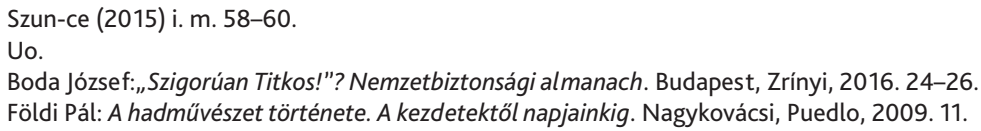


mindig a lehető legtöbb és legidőszerủbb tudás birtokában kell lennünk, és a potenciális lehetőségeket azonnal ki kell használni. Amennyiben a helyzet úgy adódik, akkor cselekedni vagy támadni kell.9

Az ókori kínai hadtudományok mélyen és szerteágazóan foglalkoznak a háború és hírszerzés tulajdonságaival. Érintik a politikatudományt, pszichológiát és filozófiát is, hiszen figyelmet fordítanak a jó és rossz vezetés, legitim és illegitim erőszak, erény és gonoszság, igazság és igazságtalanság, köz- és magánérdek, prosperálás és pusztulás kérdésköreire is. ${ }^{10}$ Clausewitz szerint a minimális erőkifejtés sem teszi feleslegessé a hírszerzés használatát. Ezzel szemben a kínai filozófus tábornokok inkább Lao Ce tanait követik, amely szerint a háborúban két feltételes erő áll egymással szemben, tehát nagyon pontos célt kell találnunk magunkban a siker eléréséhez. Ha erősek vagyunk, gyengeséget kell színlelni, ha gyengék, akkor erőt. Nem szégyen az ellenfelet csellel, álcázással, kémekkel, dezinformációval félrevezetni. ${ }^{11} \mathrm{~A}$ modern Kína a mai napig épít ezekre a hasznos, bölcs tanokra, amelyek megismerésével közelebb kerülhetünk konfliktuskezelési szokásaik, érdekérvényesítésük, módszereik és biztonságpolitikai gondolkodásuk megismeréséhez.

\section{Machiavelli ${ }^{12}$}

Niccoló Machiavellit sokan a hadtudomány egyik első klasszikusának tartják. ${ }^{13}$ A Fejedelem mellett többek között $A$ háború müvészete címủ írását is az utókorra hagyta, amiben hasznos tanácsokkal szolgál az uralkodó osztály tagjainak államuk megszervezésére, fenntartására és megvédésére. Mindezeknek természetesen az egyik legalapvetőbb és leghasznosabb eszköze a háború alkalmazása, amelyben minden eszköz megengedett - többek között a kémek, bérgyilkosok és más szolgák műveletei.

Machiavelli a hasznossági szempontokra szükíti a politika gondolatát. Eszméjének véghezviteléhez el kellett vonatkoztatnia a klasszikus filozófia rengeteg előfeltevésétől. Véleménye szerint a háborúban okozott kegyetlenség egy eszköz és ezzel a fejedelem nem okoz kárt magának. A katonai gondolkodásban éppen ezért sajátos helyet foglal el, mivel felismerte, hogy a katonai módszerek változásai összefüggnek a társadalmi és politikai térben végbemenő átalakulásokkal. Machiavelli ezen alapokra helyezi Nietzschéhez hasonlóan, a képmutatás álarcát ledobva, Titus Liviust idézve a háborút igazságosnak tartja, ha elkerülhetetlen, a módszereket pedig szükségességük igazolja.

A Fejedelem írója nem csupán a különböző titkok örzését szorgalmazza, hanem a félrevezető tájékoztatással való bánásra is különös hangsúlyt fektet. Nála a titok

\footnotetext{
Taj Kung: A háború törvényei. Budapest, Helikon, 2016. 143-158.

Szun-ce (2015) i. m. 147.

Földi (2009) i. m. 11.

12 Niccolò Machiavelli (1469-1527) olasz filozófus, hadtudós, író és politikus. Korának egyik leghíresebb gondolkodója, hatása a mai napig érezhető. Főbb müvei: A fejedelem, $A$ háború müvészete, Értekezések Titus Livius római történeteinek $X$. elsö könyve fölött, Firenze története.

13 Hegedüs Géza: Világirodalmiarcképcsarnok. Niccolo Machiavelli (1469-1527). Elérhető: www.literatura.hu/irok/renesz/ machiavelli.htm (A letöltés dátuma: 2020. 04. 02.)
} 
egyre inkább a nyilvánosság ködébe burkolózik, mivel a félrevezető látszatok használata alkalmas lehet arra, hogy megszürje az információt, többféleképpen értelmezni lehessen a minőségileg eltérő jelenségeket, ezek által a nyilvánosság atomizálttá válik. ${ }^{14}$ Révész Béla szerint azonban napjainkban a nemzetbiztonsági szolgálatok viszonylagos állandó jellege sem teszi lehetővé a titkok mozgásának olyan dimenzióit, amely visszafoglalná a nyilvános szféra függetlenségét. Ennek oka, hogy a demokratikus jogi intézmények alapértékei eltérnek ezektől a törekvésektől, nem biztosítanak szabad térnyerést, még akkor sem, ha a politikai vagy döntéshozói akarat ettől eltér. ${ }^{15} \mathrm{~A}$ totális állam gondolata nála jelenik meg először, és a korai titkosszolgálati eszközök korlátlan alkalmazásának létszükségletét is ő vetette elsőként papírra. A Fejedelemben a hatalom mindenáron való megtartásának eszköztára jelenik meg. ${ }^{16}$ Kémek, besúgók, orgyilkosok egész „seregét" kell fenntartani az uralkodónak, ha időben értesülni akar a legmegbízhatóbban mindenről. A bizalmas információkat szállítók szükségszerűen a fejedelem bizalmi körébe kerülnek be, így meg kell bizonyosodni lojalitásukról. Szun-ce egy külön kémtípust szentel annak, hogy a saját kémeit tesztelje az információk hamisságáról. Machiavelli is hasonlóan vélekedik, de ő még kegyetlenebb eszközöktől sem riad vissza. Dicsőíti Cesare Borgia példáját, aki saját emberével végeztette el a piszkos munkát, ellenségeiről hírt szerzett, majd leszámolt velük. Amikor a nép körében csatlósa már félelemet és kétségbeesést keltett, megölette azt, fellépve ezzel szeretett népének megmentőjeként.

Machiavellinél a hírszerzés erősen bizalmi munkakör. Háborús helyzetben az értesüléseket csak a legmegbízhatóbb emberek szállíthatják a fejedelem számára. Szerinte téves az a felfogás, hogy a polgárokból nem lehetnek jó katonák, mivel a köztársasági Rómában is sorozott polgárok teljesítettek hadi szolgálatokat, és a modern időkben is így kellene lennie. Ezek a katonák hüek hazájukhoz, fegyelmezettek, megbízhatóak. ${ }^{17}$ Velük ellentétben a zsoldoskatonák pénzért bármikor elárulják az embert, ezért bármilyen hírszerző tevékenység, amit végeznek, fokozott óvatossággal kezelendő.

Machiavelli hatása korunkban is érezhető, hiszen katonai elképzelései pragmatikusak és lényegre törők voltak, a jövőbe látás képességének nagy jelentőséget tulajdonított. ${ }^{18}$ Olyan kérdéseket vetett fel, amelyek függetlenek az adott történelmi korszak jellegétől, hiszen a katonai berendezkedés és a háború szerkezetét látja át a társadalom szerkezetében.

14 Niccoló Machiavelli: A fejedelem. In Niccoló Machiavelli müvei. (Fordította: Karinthy Ferenc - Iványi Norbert - Lutter Éva) Budapest, Európa, 1978. 58.

15 Révész Béla: A titok mint politika a titkosszolgálatok politológiai kutatásának lehetöségei. Doktori értekezés. Szeged, Szegedi Tudományegyetem Állam- És Jogtudományi Kar Politológiai Tanszék, 2007. 8. Elérhető: http://ww3.bibl.u-szeged.hu/bibl/eforras/tananyag/polit/abjegyzet_regi.pdf (A letöltés dátuma: 2019. 12. 20.)

16 Forgács Balázs: Napjaink hadikultúrái (A hadviselés elmélete és fejlödése tendenciái a modern korban). Doktori értekezés. Budapest, Zrínyi Miklós Nemzetvédelmi Egyetem Kossuth Lajos Hadtudományi Kar Hadtudományi Doktori Iskola, 2009. 18. Elérhető: http://m.ludita.uni-nke.hu/repozitorium/bitstream/handle/11410/9601/Teljes\%20sz\%C3\%B6veg\%21? sequence=1\&isAllowed=y (A letöltés dátuma: 2020. 04. 02.)

17 Földi (2009) i. m. 11.

18 Felix Gilbert: Machiavelli - a háború művészetének reneszánsza. In Veszprémy László (szerk.): A korai stratégiai gondolkodás. Budapest, Zrínyi, 2005. 15-32. 


\section{Zrínyi Miklós ${ }^{19}$}

Zrínyi Miklós Mátyás király életéröl való elmélkedések címü műve Machiavelli A Fejedelem művével tartalmilag szinte azonos felépítésü: mindkettő gyakorlatilag királytükröt állít az uralkodó elé, és bemutatja a jó kormányzás ismérveit. Machiavelli $A$ háború müvészete címủ műve pedig a Tábori kis tracta című kézikönyvvel mutat hasonlóságot, mivel mindkettő az uralkodó hadseregre való támaszkodásának sarkalatosságát hangsúlyozza. ${ }^{20}$ Machiavelli már A Fejedelemben is kiemeli, hogy a hadsereg alkalmazása és fenntartása mennyire fontos mint az uralom stabilitását biztosító egyik alapeszköz. ${ }^{21} \mathrm{~A}$ hírszerzés is lényeges elemmé válik Zrínyinél. Ő a lovasság kiemelkedő szerepét hangsúlyozza a felderítés és portyák tekintetében. ${ }^{22}$

Zrínyi Miklós a Vitéz Hadnagy című művében Montecuccolihoz hasonlóan az alapos tervezés, az abszolút megalapozottság fontosságát hangsúlyozza. Tartózkodni kell a csapongó hadműveletektől, a legnagyobb óvatossággal szabad csak előrenyomulni, folyamatosan hátrafelé is figyelni kell, minden egyes lépést meg kell előre tervezni. Zrínyi szerint a csaták elkerülése a cél elérése érdekében teljesen elfogadható. A kapitánynak ugyanis nem kell mindig csupán a harcra gondolnia, amennyiben vannak más eszközei: az ellenséget meg lehet verni más csalárdsággal is. ${ }^{23}$ Ezekhez a csalafinta műveletekhez javasolja kémek és hírszerzők alkalmazását, a katonai felderítéshez pedig gyorsan mozgó lovascsapatokat. ${ }^{24}$ Zrínyi Miklós úgy gondolja, hogy akár a hadvezér, akár az uralkodó, ha kémeket alkalmaz, az nem egy alattomos alak, hanem épp ellenkezőleg: a vitézség szekere ezek nélkül nem jár, megbotlik, beragad. A kémeket bőségesen meg kell fizetni, hiszen könnyen ellenünk fordíthatók, de ha segítségükkel akárcsak egyszer is meglehet verni az ellenséget, már megfizették az árukat. ${ }^{25}$

A híres hadvezér és költő egyenesen azt javasolja, hogy maga a király ismerje a legjobban a cseleket. A király 2. legfőbb mestersége nem más, mint a diversio, azaz az ellenség figyelmének elterelése, mégpedig nem csupán kis dolgokkal. Zrínyi Mátyás király életéről való elmélkedések címü művében elismerően nyilatkozik Mátyás jól kitervelt elterelő műveletéről Lengyelország ellen, hiszen míg Szapolyai János és Kinizsi Pál hadai dúlták fel az országot, ő rá tudta kényszeríteni akaratát a kényszerhelyzetben lévő, többoldalú támadástól tartó ellenfelére. ${ }^{26}$

Mátyás a sikereket portyázásokkal, váratlan rajtaütésekkel és elszigetelt várak elfoglalásával érte el, továbbá, hogy ezeket a módszereket kombinálva használta. Míg egy nagyobb sereg elterelte az ellenség figyelmét az ország egyik részében, ő kisebb csapatokkal feldúlta a másik részét. Kémhálózata révén jól ismerte az ellenség erejét és mozdulatait. Fontosabb ütközetek előtt személyesen is részt vett a felderítésben,

19 Zrínyi Miklós (1620-1664) fönemes, költő, politikus, hadvezér, hadtudós. Főbb művei: Tábori kis tracta, Vitéz hadnagy, Mátyás király életéröl való elmélkedések, Ne bántsd a magyart - Az török áfium ellen való orvosság.

20 Hegedüs i. m.

21 Machiavelli (1978) i. m. 58.

22 Hausner Gábor: Adalékok a XVII. századi katonai gondolkodás történetéhez. In Ács Tibor (szerk.): A magyar katonai gondolkodás története. Budapest, Zrínyi, 1995. 50-52.

23 Perjés Géza: A „,metodizmus” és a Zrínyi-Montecuccoli vita. In Veszprémy László (szerk.): A korai stratégiai gondolkodás. Budapest, Zrínyi, 2005. 87-133.

24 Kovács Sándor Iván (szerk.): Zrínyi Miklós prózai müvei. Budapest, Zrínyi, 1984. 129

25 Boda (2016) i. m. 52.

26 Zrínyi Miklós: Mátyás király életéről való elmélkedések. Budapest, Magyar Bibliofil Társaság, 1990. 
ahogy azt a mondákból is ismerhetjük. Jeneyhez hasonlóan Zrínyi is a lovasságot tartja a felderítés első számú eszközének, ahogy Mátyás is kiválóan bánt lovasságával. A könnyen mozgó csapatok gyorsan hírt tudtak szerezni és visszajuttatni azt a főhadiszállásra.

\section{Jeney Lajos Mihály ${ }^{27}$}

Jeney Mihály Lajos fő műve A portyázó, avagy a kisháború sikerrel való megvívásának mestersége korunk géniusza szerint a kor egyik legfontosabb magyar hadtudományi értekezése a kisháborúkról szóló munkák közül. A portya körülményeit minden esetben egyedinek tekintette, ezért a csapatok nagyságát és arányát mindig az adott helyzethez javasolta igazítani. ${ }^{28}$ A sikeres portyázással kapcsolatos katonai tevékenység alapvető részének tekintette a felderítést, lesvetést, a rajtaütést és a visszavonulást. Könyvében külön fejezetet szentel a felderítésnek: a IX. fejezet ténylegesen meghatározza, hogy a portyákat milyen céllal kell elindítani. Feladat az ellenség és vidék figyelése, az utak szemmel tartása, a táj előnyeinek és hátrányainak megismerése, az ellenség állásainak, mozgásának és erőinek kiismerése. A felderítő portyának nem szabad 12-20 embernél többől állnia, hiszen nagyobb számú csapat nem lopakodhat olyan észrevétlenül, mint egy kisebb. Viszont akár több csapat is kiküldhető egyszerre. A jó felderítéshez elengedhetetlen a gyors mozgás, ezért gyalogoscsapatok alkalmazása nem javasolt, csak a lovasság megfelelő a feladat ellátására. Jeney szerint legalább egy tisztnek részt kell vennie a felderítésben és irányítania a csapatot, mivel egy magas rangú ember nem riadhat vissza kisebb kompániák vezetésétől sem. Ráadásul a feladat igen fontos, mivel az itt szerzett információk határozhatják meg az azt követő portyák menetét. A felderítő portyáknak elengedhetetlen szereplője még a geográfus, aki a látottakból jegyzetet készít. Lebukás esetén az ő menekülése a legfontosabb, a leírt vázlatait és gondolatait nem szabad az ellenség kezére juttatni, minél előbb vissza kell térni vele saját táborába. Minden különös sajátosságot fel kell jegyeznie: a hegyeket, dombokat, utakat, úttorkolatokat, réteket, folyókat, patakokat, hidakat, átjárókat, szántóföldeket, vízmosásokat, falvakat, városokat, kastélyokat, tanyákat, majorságokat és minden ezekkel kapcsolatos információt. ${ }^{29}$

Mint látható, ezeknek a megbízásoknak a sikere nagymértékben függ a titoktartástól. Ezért a fejedelemnek, aki a felderítő portyát szervezi, rendkívül körültekintőnek kell lennie, és csak a legmegbízhatóbb embereket szabad kiválasztani a feladatra. A siker kulcsa az, hogy a küldetés mennyire marad titokban. Ha legkisebb mértékben is fenn áll a lebukás esélye, azonnal vissza kell vonulni. Szun-cével és Zrínyivel ellentétben úgy vélekedik, hogy a titoktartás miatt mindenféle harci tevékenységet is el kell kerülnie a vezérnek, még akkor is, ha a siker biztosnak tünik. Jeney tisztában

7 Jeney Lajos Mihály (1723 vagy 1724-1797) vezérőrnagy a 18. századi magyar katonai gondolkodás kiemelkedő alakja.

28 Forgács Balázs: Hadelmélet. A Magyar katonai gondolkodás története és a hadikultúrák. Budapest, Dialóg Campus, 2017. 18. Elérhető: www.uni-nke.hu/document/uni-nke-hu/5.\%20Forg\%C3\%A1cs\%20jegyzet.pdf (A letöltés dátuma: 2020. 04. 02.)

29 Jeney Mihály Lajos: A portyázó, avagy a kisháború sikerrel való megvívásának mestersége korunk géniusza szerint. Budapest, Magvetö, 1986. 108-113. 
van vele, hogy az ellenség is alkalmaz spionokat. Ezért kívánatos olyan embereket kiválasztani a portyára, akik beszélik az ellenség nyelvét, és érdemes felszerelni őket az ellenség ruházatával. A szerző maga is szert tett gyakorlati tapasztalatokra 1757ben, amikor Vesztfáliában szolgált. ${ }^{30}$

Zrínyi Miklósnál és Jeneynél is látható, hogy mennyire alapvető és nélkülözhetetlen egy jó kém- és információhálózat fenntartása. A török háborúk idején azonban szervezetszerűen müködő hírszerzés nem létezett a szétszakadt Magyarországon, ami Boda József szerint főképp pénzügyi okokkal magyarázható. A többi nemzethez hasonlóan zömmel kereskedők és vándorok segédkeztek az ellenség felderítésében. A felderítés a kialakult helyzet miatt támadó jellegű volt, az ellenség folyamatos izgatása, zaklatása jellemezte, amikhez lesállásokat vetettek és rajtaütéseket hajtottak végre. A felderítésben 10-20 fös lovas járöröktől kezdve a 2-3 ezer embert számláló lovasdandárokon át a tábornokokig mindenki részt vett. ${ }^{31}$

\section{Carl von Clausewitz ${ }^{32}$}

Clausewitz a hegeli dialektika intuitív hatására tagadja a hadművészetben a változatlanságot. Számos gondolkodóval ellentétben nem tartja a hírszerzést és kémkedést nagy jelentőségűnek a háborúk megnyerése céljából. Az információk gyorsan képesek elavulni, a háborúban gyakran egymásnak ellentmondanak, tévesek lehetnek, és a rendelkezésre áll egyébként is szervezettség nélkül a szükséges tudás. Csupán azokat az adatokat szükséges számon tartani, amelyek állandók: ilyen lehet a terep adottsága, városok, utak, folyók, erődítmények elhelyezkedése, az ellenség erőinek ismerete. ${ }^{33} \mathrm{~A}$ háborús szünet számára egy újabb magyarázat az áttekinthetetlenségre. Kézenfekvő lenne, hogy a szünetben az ellenséget kémleljük minden erőnkkel, ám ez elhagyható. Az információ hiánya képes lehet felgyorsítani a hadieseményeket, még a politikai és hadászati kettősség miatt éppen ellenkezőleg, lassulás fog bekövetkezni. A hadműveletek közben beálló gyakori szünetelés a háborút fokozatosan eltávolítja annak abszolút jellegétől, ezáltal a felek valószínűségszámításokba fognak bocsátkozni. ${ }^{34}$ Ebből kifolyólag látható, hogy mindenféle számítgatás, esélylatolgatás, feltételezés a bizonytalan felé sodorja csak a gondolkodót, így hadi szünetekben sem szükséges a hírszerzés erőltetése. Így tehát követve Machiavelli gyors lefolyású háborújának elméletét, a háborús szüneteket minél előbb be kell fejezni, és a háborút a leggyorsabban le kell zárni.

Szun-ce a háborút minden esetben a tervek lefektetésével kezdi. A háború, a csata előtt mindenre kiterjedő feltáró intézkedéseket kell tenni, és semmilyen részletet sem szabad elhanyagolni. Clausewitz azonban úgy gondolja, hogy ezek az erőfeszítések

\footnotetext{
Jeney (1986) i. m. 108-113.

Boda (2016) i. m. 52.

Carl Philipp Gottlieb von Clausewitz (1780-1831) porosz katonatiszt, katonai teoretikus, a hadtudomány egyik legföbb alapmüvének $A$ háborúról (Vom Kriege) című münek a szerzője. Az újkori hadászat elméletének úttörője, a háború mint a politika folytatása más eszközökkel tézis megalkotója.

33 Carl Von Clausewitz: A háborúról. Budapest, Athenaeum Irodalmi és Nyomdai Részvénytársaság, 1917. 71-72.

34 Tóth I. János: Clausewitz a háború lényegéröl. Létünk, (2014), 3. 25-41. Elérhető: http://publicatio.bibl.u-szeged. hu/5001/1/Clausewitz\%20a\%20h\%C3\%A1bor\%C3\%BA\%20l\%C3\%A9nyeg\%C3\%A9r\%C5\%91l\%20by\%20 t\%C3\%B3th.pdf (A letöltés dátuma: 2020. 04. 04.)
} 
elegendőek, ha csak az ellenség tüzerejére és haditervére, a terep adottságaira és az időjárásra összpontosítódnak. Szun-ce szerint a belsős információk megszerzése, mint például kormányzati tervek vagy eljárások megismerése ugyanolyan fontos a győzelem szempontjából, mint a katonai hírek. Clausewitz viszont feleslegesnek tartja ezeket a lépéseket. Úgy véli, az adatok megszerzésének és értelmezésének van egy felső határa, és egyszerüen nincs elég idő mindent felmérni, ami a győzelemhez, ezáltal saját akaratunk ellenfelünkre kényszerítéséhez segítene. Azzal érvel, hogy habár egyes konkrét kormányzati döntéseket meg lehet tudni, de a lényeg a mögöttes tartalomban van, ami gyakran a legközelebb álló döntéshozók számára sem publikus.

Véleménye szerint senki sem rendelkezik mindent átfogó ismeretekkel és gyakran a tényleges helyzet eltérhet az általunk kapott tájékoztatásoktól. A haditervek és a valóság közötti eltéréseket surlódásoknak nevezi. ${ }^{35}$ Helmuth von Moltke, akire nagy hatással volt Clausewitz írása úgy fogalmaz, hogy „egy haditerv sem éli túl az első találkozást az ellenséggel". Clausewitz 3 okot vázol fel: 1. Hiányos és hamis információk: Az információ nagy része a háborúban a gyorsan változó körülmények miatt hamis vagy ellentmondásos. A tervek gyakran hazugságokon vagy hiányosságokon, alapulnak, ezért hibásak lesznek. A politika felől érkezdő adatok a politika természetéből adódóan lehetnek túlzók, részben elavultak vagy manipuláltak. 2. Érdekérvényesítés a ködben: A háború a bizonytalanság terepe. A harcnak több területe is könnyen megváltozhat nagyobb vagy kisebb mértékben menet közben. Példaként hoz időjárással kapcsolatos befolyásoló tényezőket. 3. A politika olyan, mint egy kártyajáték: A súrlódás oka még a legjobb haditerv és a valóság között az is, hogy a háború a lehetőségek játéka, tele van választásokkal, valószínüségekkel, jó és rossz szerencsével, akár egy kártyajáték. ${ }^{36}$

Clausewitz szerint lehetséges készülni a beláthatatlanra. A dolgokat kauzalitásukban kell vizsgálni, és készen kell állni a stratégiát megváltoztatni, amennyiben beláthatatlan történések veszélyeztetik a haditervet. Mindig szükséges specifikus célokat szem előtt tartani, és akként cselekedni, amit a szükség és a helyzet megkíván. Folyamatosan az ellenség meglepésére kell törekedni, nem szabad neki előnyt biztosítani. ${ }^{37}$ E módszerekhez azonban háború közben nem szükséges egy ügynökhálózat fenntartása. Alig szentel figyelmet a hírszerzés fontosságára, a biztos tudás megszerzésén kívül nem foglalkozik vele tovább, viszont nem tagadja annak létjogosultságát a politikai és hadi térben.

Carl von Clausewitz sokkal tudományosabb és analitikusabb író, mint a korábban bemutatott szerzők. Pragmatizmusa egyértelmúen a felvilágosodás jeleit mutatja magán. A hadtudományban egy fordulatot jelent $A$ háborúról címü klasszikusa. A felderítésről, információszerzésről írott gondolatai egy választóvonalat jelentenek a korábbi szerzők és az őt követő gondolkodók között. Clausewitz az egyike azon hadtudósoknak, akik a legminimálisabban javasolják a felderítés és hírszerző rendszerek alkalmazását, és spekulációk helyett realista módon értelmezi a háború természetének leírását. Absztrakt értelmezésével ellentétes, némileg antagonisztikus a felderítés és tervek ilyen mértékü mellőzése: a háború a természeténél fogva eszkalálódik, fokozottan növelve mind a két fél részéről az erőket, így a hírszerzők és kémek alkalmazása is indokolt lenne, legfőképpen akkor, ha a másik fél is él ezzel a lehetőséggel.

35 Clausewitz (1917) i. m. 72-74.

36 Matthijs Pars: Six strategy lessons from Clausewitz and Sun Tzu. Journal of Public Affairs, 13. (2013), 3. 329-334.

37 Uo. 


\section{Antoine-Henri Jomini ${ }^{38}$}

Jomini legföbb elemzéseit a stratégia fogalomkörére szűkítette, fő alapját a hétéves háború és a napóleoni háborúk szolgáltatták. A stratégiát tartja a hadviselés kulcsának: nagy tömegű erők kisebb tömegü erők elleni, megfelelő időpontban és helyen mért csapásának. ${ }^{39} \mathrm{Az}$ orosz cári udvar segítőjeként készítette el fö összefoglaló művét A hadtudomány összefoglaló elemzése címmel, majd ennek az írásnak a kibővített változatát, A hadmüvészet kézikönyvét. A döntő pont fontosságát emeli ki a háborúkban. Véleménye szerint Napóleonnak ez volt a fö erénye. Mindig tudta elöre, az ellenség mely pontját kell támadni, mik azok a tényezők, amelyek a legtöbb előnyt jelentheti számára a hadjárat megnyerésének érdekében. Zseniális húzásainak fő magyarázta az volt, hogy mindig igyekezett a legtöbb információt összegyüjteni ellenfele összes lehetőségéröl és helyzetéről. Jomini $A$ hadmüvészet kézikönyve című müve 6 . fejezetének XVII. cikkelyében leírja gondolatait a hatékony információszerzésről. Hasonlóan Clausewitzhez, nem tartja észszerünek a gyorsan változó háború keretein belüli hírszerzést. Az 1812-es évet hozza példaként, mikor Napóleon az oroszországi hadjáratát vezette. Az orosz hadvezetésnek sokat segítettek az orosz kozákok és partizánok az elfogott francia levelekkel és az ellenséges csapatok mozgásáról való tájékoztatásokkal, de mégsem tartotta őket fontosnak. Az oka nem más, mint a nehéz kommunikáció, az információk kijuttatása az ellenség vonalai mögül a saját parancsnokságra. ${ }^{40}$ Ezek helyett sokkal hasznosabbnak tartotta a stabil kémek és felderítők használatát, akik megingathatatlan információkat tudnak hazajuttatni. Hírszerző- és kémhálózat szempontjából Napóleon módozatait tartja ildomosnak, akinél ez a terület is lépést tartott a diplomáciai és katonai szolgálati ág hadművészeti és harcászati fejlődésével. lgyekezett minden birodalom udvarában hozzá hü, önálló, felelős embereket megnyerni magának, őket pedig mindig határozott utasításokkal látta el. A magasabb rangú tisztségviselőkön kívül föképp hozzá hű tiszteket alkalmazott információszerzésre. 1806-ban, mikor Poroszországot akarta megtámadni, Thüringián keresztül tervezte elérni Berlint. Olyan térképekkel nem rendelkezett azonban, amelyeket használhatott volna, így több hónapra két tisztjét küldte álruhában az ellenséges vonalak mögé, hogy geográfiai adatokat gyűjtsenek számára. Clausewitz „biztos tudás” koncepciójával Jomini is egyetért, Napóleon is mindent tudott ellenségei seregeinek felépítéséröl és állapotáról, nem fordulhatott elő, hogy egy zászlóalj úgy változtasson helyet, hogy ő ne tudjon róla. ${ }^{41}$ Azonban egy kémnek nem szabad túllépnie a kereteit: pletykáknak nem ad hitelt, csak az a biztos, amit a saját szemével lát, és ezekből az információkból készíti el jelentését. Hadi állapotok közepette a kémek és felderítők ténykedésének köre az ellenség mozgásával kapcsolatos információk megszerzésére kell irányuljanak, amelyhez a lehető legtöbb forrásból kell adatokat szerezni, nem számít mennyire tökéletesek vagy ellentmondásosak, az igazság gyakran elválik tőlük. Ezen okból

38 Antoine-Henri Jomini (1779-1869). Legföbb elemzéseit a stratégia fogalomkörére szükítette, fő alapját a hétéves háború és a napóleoni háborúk szolgáltatták. Megjelent művei miatt gyorsan híressé vált mint történész és katonatudós, dacára annak, hogy otthagyta a francia hadsereget, és 1813-tól egészen haláláig az orosz cár, I. Miklós katonai tanácsadója lett.

39 Forgács Balázs: A néppel az uralkodóért. Az első gerillaelméletek. Felderitő Szemle, 15. (2016), 1. 21-57.

40 Uo.

41 Pilch Jenő: A hírszerzés és kémkedés története I. Budapest, Kassák, 1998. 278-283. 
kifolyólag egyetlen eszközre sem szabad kizárólagosan támaszkodni. A tökéletes információ megszerzése szerinte is lehetetlen, ezért a hadvezérnek mindig több forgatókönyvvel is rendelkeznie kell, amit a seregek relatív helyzetei lehetővé tesznek számára, de a hadművészet alapelveit nem szabad soha figyelmen kívül hagynia. ${ }^{42}$

Habár az intézményrendszer valódi kiépülésére még évtizedeket várni kellett, azt láthatjuk Clausewitznél és Jomininél is, hogy a hírszerzés gyakorlatában már megjennek náluk modern gyakorlatok. Párhuzamot vonhatunk a 19. és 20. századi ügynökhálózatokkal, kezdetleges formájuk megjelent az I. világháború előtti években kialakított, már központilag szervezett hírszerző ügynökségek között. ${ }^{43} \mathrm{~A}$ kor tudományos vizsgálódása főképp a weberi ideáltípusukra, a társadalom és politikai viszony normál állapotára, a célracionális és értékracionális cselekvések megértésére koncentrálódott, az extrém állapotokkal ritkábban foglalkoztak. Ez oka lehet annak, hogy Clausewitz a hírszerzés jelenségét a hadtudományban elsőként, már mint politológiai kérdés is értelmezte, így a háború kivételes állapota miatt a hírszerzés is a vizsgálatok tárgyát képezte nála. Sokáig nem került a tudományos érdeklődés centrumába az információgyüjtés kérdéskörének kutatása, elmondhatjuk, hogy a politikai térbe ő helyezte a kutatásokat - bár neki nem ez volt az elsődleges szándéka. ${ }^{44}$

A titoktípusok közül a rivális döntéshozókat a 19. századtól kezdve egyre inkább a politikai tartalmat hordozó információk kezdik el érdekelni. A politikai információk kezdenek prioritássá válni, de a hadititkok sem maradnak figyelmen kívül. Elkezdődik a két típus intézményrendszerbe tömörülése.

\section{Következtetések}

A történelem folyamán a döntéshozók, hadvezérek és gondolkodók szinte mindig keresték a módszerét az ellenség minél hatékonyabb megismerésének. Napjainkban kiváltképp jellemző, de már a korábbi korszakokról is elmondható volt, hogy bizonyos tudás segítségével a közvetlen összecsapás elkerülése volt a cél.

Az információ birtokában való döntéshozás mindig megelözi a háborút - de a háborúban az információ birtoklása is elősegíti a győzelmet. A felvázolt szerzők sok esetben különbözőképpen értékelik a hírszerzés jelentőségét, de egyetemes gondolatokat is megfogalmaznak. Már az első közösségek, államok idején megjelent egzisztenciájuk védelme érdekében a titkaik megörzése és az ellenérdekelt fél titkai megszerzése iránti vágy. Ezért a hatalom a titok megszerzésének és megőrzésének módszereit hierarchikus rendszerbe osztotta be. A hierarchiában lesz egy személy, aki a titkokat privilégiumként kezeli, autoritása van felettük, és hatalmát meghatározza, hogy az állam- és hadititkok mekkora birtokában van..$^{45} \mathrm{~A}$ hatalom ténylegesen annak a kezében van, aki a belső és külső titkok legnagyobb hányadát birtokolja. A bizalmas

42 Antoine Henri Jomini: The Art of War. Kingston, Ontario, Legacy Books Press Classics, 2008. 214-221.

43 Huw J. Davies: Spying for Wellington: British Military Intelligence in the Peninsular War. Norman, University of Oklahoma Press, 2018. 247-257.

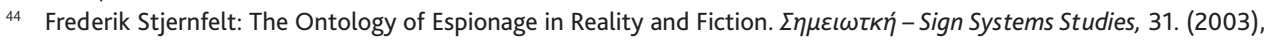
1. 133-162.

45 Révész (2007) i. m. 6. 
információk megszerzésének és felhasználásának módszereiben a pragmatizmus figyelhető meg náluk.

A klasszikusoknál a bizalom kulcsfontosságú az információk megszerzése szempontjából, hiszen technológia híján csak a megbízott személyek szavára támaszkodhattak. Szervezetrendszerü hírszerzés nem jellemző, erre a 19. századig a legtöbb helyen várni kellett, és akkor is fenntartásokkal kezelték. Az ok a már említett bizalom kérdéskörében keresendő, a döntéshozók a lehető legkevesebb emberen keresztül szerették volna a titkokat birtokba venni. Korunkban ezt a belső konspirációval próbálják megakadályozni a különböző minősített információkkal dolgozó szervezetek.

A kihívások, kockázatok és fenyegetések átalakulásai, amelyekkel a politikának is aktívan kell foglalkoznia, egyre gyakrabban támaszkodik a nemzetbiztonsági szervezetrendszerre. Szun-ce, Taj Kung, Machiavelli, Zrínyi, Jeney, Clausewitz, Jomini ugyan eltérő szemlélettel, de mind egyetértenek abban, hogy az információszerzés esszenciális része a biztonsági kérdéseknek. Mint láthattuk, a hadtudományi megközelítés elengedhetetlen, és más területeknek (például a politológiának) is be kell építenie saját behatárolt területén folytatott kutatások között a megszerzett tudást. ${ }^{46}$

\section{Felhasznált irodalom}

Babos Sándor: A katonai hírszerzés és a katonai elhárítás hadtudományi természete. Felderitö Szemle, 17. (2019), 2. 146-158. Elérhetö: www.knbsz.gov.hu/hu/letoltes/ szsz/2019_2_szam.pdf (A letöltés dátuma: 2020. 04. 02.)

Boda József: „Szigorúan Titkos!”? Nemzetbiztonsági almanach. Budapest, Zrínyi, 2016. Clausewitz, Carl Von: A háborúról. Budapest, Athenaeum Irodalmi és Nyomdai Részvénytársaság, 1917.

Davies, Huw J.: Spying for Wellington: British Military Intelligence in the Peninsular War. Norman, University of Oklahoma Press, 2018.

Forgács Balázs: A néppel az uralkodóért. Az első gerillaelméletek. Felderítő Szemle, 15. (2016), 1. 21-57.

Forgács Balázs: Hadelmélet. A Magyar Katonai Gondolkodás Története és a Hadikultúrák. Budapest, Dialóg Campus, 2017. Elérhető: www.uni-nke.hu/document/uninke-hu/5.\%20Forg\%C3\%A1cs\%20jegyzet.pdf (A letöltés dátuma: 2020. 04. 02.) Forgács Balázs: Napjaink hadikultúrái (A hadviselés elmélete és fejlödése tendenciáia modern korban). Doktori értekezés. Budapest, Zrínyi Miklós Nemzetvédelmi Egyetem Kossuth Lajos Hadtudományi Kar Hadtudományi Doktori Iskola, 2009. Elérhető: http://m.ludita.uni-nke.hu/repozitorium/bitstream/handle/11410/9601/Teljes\%20 sz\%C3\%B6veg\%21?sequence=1\&isAllowed=y (A letöltés dátuma: 2020. 04. 02.) Földi Pál: A hadmüvészet története. A kezdetektöl napjainkig. Nagykovácsi, Puedlo, 2009. Gilbert, Felix: Machiavelli - a háború művészetének reneszánsza. In Veszprémy László (szerk.): A korai stratégiai gondolkodás. Budapest, Zrínyi, 2005. 15-32.

46 Babos Sándor: A katonai hírszerzés és a katonai elhárítás hadtudományi természete. Felderitő Szemle, 17. (2019), 2. 146-158. Elérhető: www.knbsz.gov.hu/hu/letoltes/szsz/2019_2_szam.pdf (A letöltés dátuma: 2020. 04. 02.) 
Hausner Gábor: Adalékok a XVII. századi katonai gondolkodás történetéhez. In Ács Tibor (szerk.): A magyar katonai gondolkodás története. Budapest, Zrínyi, 1995. 50-52. Hegedűs Géza: Világirodalmi arcképcsarnok. Niccolo Machiavelli (1469-1527). Elérhető: www.literatura.hu/irok/renesz/machiavelli.htm (A letöltés dátuma: 2020. 04. 02.) Jeney Mihály Lajos: A portyázó, avagy a kisháború sikerrel való megvívásának mestersége korunk géniusza szerint. Budapest, Magvető, 1986.

Jomini, Antoine Henri: The Art of War. Kingston, Ontario, Legacy Books Press Classics, 2008.

Kovács Sándor Iván (szerk.): Zrínyi Miklós prózai müvei. Budapest, Zrínyi, 1984.

Machiavelli, Niccoló: A fejedelem. In Niccoló Machiavelli müvei. (Fordította: Karinthy Ferenc - Iványi Norbert - Lutter Éva) Budapest, Európa, 1978.

Pars, Matthijs: Six strategy lessons from Clausewitz and Sun Tzu. Journal of Public Affairs, 13. (2013), 3. 329-334. DOI: https://doi.org/10.1002/pa.1460

Perjés Géza: A „,metodizmus” és a Zrínyi-Montecuccoli vita. In Veszprémy László (szerk.): A korai stratégiai gondolkodás. Budapest, Zrínyi, 2005. 87-133.

Pilch Jenő: A hírszerzés és kémkedés története I. Budapest, Kassák, 1998.

Révész Béla: A titok mint politika. A titkosszolgálatok politológiai kutatásának lehetöségei.

Doktori értekezés. Szeged, Szegedi Tudományegyetem Állam- és Jogtudományi Kar Politológiai Tanszék, 2007. Elérhetö: http://ww3.bibl.u-szeged.hu/bibl/eforras/ tananyag/polit/abjegyzet_regi.pdf (A letöltés dátuma: 2019. 12. 20.)

Stjernfelt, Frederik: The Ontology of Espionage in Reality and Fiction. $\Sigma \eta \mu \varepsilon ı \omega \tau \kappa \eta ́-S i g n$ Systems Studies, 31. (2003), 1. 133-162.

Szun-ce: A háború múvészete. Budapest, Helikon, 2015.

Taj Kung: A háború törvényei. Budapest, Helikon, 2016.

Tóth I. János: Clausewitz a háború lényegéröl. Létünk, (2014), 3. 25-41. Elérhető: http://publicatio.bibl.u-szeged.hu/5001/1/Clausewitz\%20a\%20h\%C3\%A1bor\%C3\%BA\%20l\%C3\%A9nyeg\%C3\%A9r\%C5\%911\%20by\%20t\%C3\%B3th. pdf (A letöltés dátuma: 2020. 04. 04.)

Zrínyi Miklós: Mátyás király életéröl való elmélkedések. Budapest, Magyar Bibliofil Társaság, 1990. 
